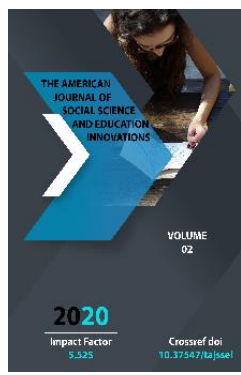

\title{
Linguistic Properties Of Proverbs Used In Uzbek Folk Epics
}

\author{
Sh. Mahmadiev \\ Candidate Of Philological Sciences, Associate Professor, Samarkand State University, \\ Uzbekistan
}

Copyright: Original content from this work may be used under the terms of the creative commons attributes 4.0 licence.

\section{ABSTRACT}

The article examines the functional-semantic and methodological features of proverbs specific to the text of epics. It focuses on dialectal proverbs, their variants, scope and lexical-semantic aspects.

\section{KEYWORDS}

Bakhshi, global culture, Alpomish, Yodgor, Barchin, Kultay, folklore, epic, application, mullah, dialect, proverb, saying, Parmeological dictionary, phraseology.

\section{INTRODUCTION}

A large part of the rich spiritual riches that have come down to us from our ancestors are examples of folklore. The views of the President Sh. Mirziyoev "It is well known that the priceless masterpieces of culture created by mankind are first of all embodied in the folk art of each nation. The art of bakhshi (a narrator who know epics by heart), which expresses the national identity of different peoples, their language and way of life, traditions and customs, is valuable for all of us as an integral part of universal culture. These immortal works of the world cultural heritage tell us that humanity has a lineage, historical roots, noble ideals, and, consequently, common aspirations of different nations and peoples. At the same time, it is no secret that in the current era of globalization, "global 
culture", which has become a means of commerce, the attention and interest in folk art, which is the source of any national culture, is declining. However, the art of folklore, so to speak, is a childhood song of mankind [1, 2019]" serve as a methodological basis in scientific research as a vital conclusion.

After all, these views encourage a broad study of the history of the language of our people, the linguistic structure of folklore works that are an integral part of it.

In this regard, it is important to study the linguistic features of proverbs in the text of epics, which are popular among our people. Uzbek linguistics is characterized by the researches of H.Abdurahmanov, B.Urinbaev, S.Tursunov, B.Toychibaev, K.Yuldashev, K.Bozorbaev, A.Khalikov, devoted to the coverage of the linguistic features of folklore, in particular, proverbs [2, p 26]. At the same time, our scholars such as $\mathrm{H}$. Doniyorov, $\mathrm{H}$. Berdiyorov, R. Rasulov, M. Khakimov, U. Mirzakarimova, B. Yuldashev, S. Karimov, A. Abdusaidov, B.Soatov, B.Juraeva, N.Usmonov who made special observations on certain aspects of proverbs in Uzbek linguistics and folklore a number of studies directly or indirectly related to the topic are of particular importance [3, p. 24]. Based on such research, it is necessary to consistently study and continue the role of folk proverbs in the text of epics, their application in certain creative works, the features of individuality and tradition. The articles in the series "Alpomish" narrated by Fozil Yuldosh oglu, in particular, in the text of the epics "Alpomish" and "Yodgor", which are the object of our study, can be studied in the following groups:

\section{Proverbs used in literary language and Uzbek folk dialects.}

Such proverbs have been used in the history of our language and are still used in literary language [4, pp. 10-12].

In the text of the epics we studied, the following appearances were observed: "Sulton suyagini xorlamas - The sultan does not despise the friend", "ikki yorti bir butun- two halves a whole", "elakka borgan xotinning ellik og'iz gapi bor- the woman who went to the sieve has fifty sayings", "sichqonning ini ming tanga bo'Imoq the mouse's nest is a thousand coins", "Do'stga zor aylama, dushmanlarga xor - Do not oppress a friend, despise enemies", "omonat - omonat qilmaysan xiyonat - deposit - betrayal you do not make a deposit", "esing borida etagingni yop take yourself into control while you are conscious", "Davlat eshigin sabr ochar, besabrdan davlat qochar - Patience opens the door to the state, the state flees from impatience", "yo'l tanisang, o'z joyingni top - If you know the way, find your place", "g'am ema, beg'am ham bo'lma - do not worry, do not be without worry", "eldan el ketsa - mehnat, elga el qo'shilsa - davlat - if the hand goes hand in hand - labor, if the hand joins the hand - the state", "elga el qo'shilsa - davlat, eldan el ketsa mehnat - if the hand joins the hand - the state, if the hand leaves the hand - labor", "haqiqat o'z joyin topar - the truth finds its place", "yo"l bilmasang, yo'l so'ra yurgandan, gap bilmasang, gap so'ra bilgandan - if you don't know the way, ask for directions, if you don't know the way, ask for directions", "sabr tegi sarig'oltin - patient it the key to the happiness", "baliqning yorug'ligi suv bilan - the survival of the fish with water", "arining uyasiga tegsang, o'rtaga olib talaydi - If you touch the bee's nest, it will come to you".

The content and essence expressed in the above proverbs are still widely used in the vernacular. Therefore, such general proverbs 
used in the works of the poet Fozil served to ensure the clarity and comprehensibility of the realities, the expression of firm judgments and

Conclusions. Alpomish returned, when he came home, Barchin did not calm down: "Sulton suyagini xorlamas - The sultan does not despise the friend" - there is a question, in your ease, will my father be humiliated in the land of stay, - says this word (A-209); When he heard this from Yodgor, he said, "well done, my son, if you are a mother, so be it". "I'm coming from a sheep, and I'm going to go to this kid's wedding, and I'm going to break it as best I can. After all, my son, go and see the "grandfather" breaking the wedding (A-345); Grandpa, sit down, since there is no bread, I will bring a sieve from my neighbor, and I will give you a baked bread and put some oil on it. He went to the sieve, and there were five or six women talking. "The woman who went to the sieve has fifty sayings", he said, and he went on with the women. The talk escalated and Kultay forgot (A-334); If you give such a touch, one day it will come, it will be a disaster for us, it will cost us a thousand coins. If you leave me, let it be six months, we are always single, and I want to put this Uzbek girl in jail" he said. The braves said that and went back to the season. (A-68); My beautiful horse is a trust to you, you do not betray the trust (A-96); When Alpomish heard that Kalmak was dead, the elders of Shamirat and the tribe said, "take yourself into control while you are conscious". Let us move from Boysun without any trouble, and when the land is calm, we will return, and we will find our husband, our husband, and our land" (Jod. 8); Hearing this from Yodgor, his mother Barchin said: - My son, where did you hear that?! I was walking so as not to touch your heart. "As the life of a fish is with water, so my life is with you (Yod.-31); My son, there are so many of them,
"If you touch bee's nest, he will snatch it". Are you alone, scattering dust? It is a sin for you to be attached to them if they do not abuse you. We are a little hand, they are many, if they vibrate, they will step on our bar and trample on our feet, it is impossible to be equal to them, - he said (Yod.-69).

\section{Proverbs in epic language and their current variants.}

In the text of the epics studied, proverbs were used in such a way that their form was used in a style typical of epics, which logically corresponds to the variants of modern proverbs. For example, Mullahs recite duos; peasants dig the land (A-83). This proverb can be considered as a variant of the proverbs in the modern literary language: "Mullah recites what he knows, weaver spins what he knows", "Mullah recites what he knows, the chicken pecks what it sees", and "If you are a mullah, repeat, if you are a farmer, cultivate" [5, p. 141]. So, both of these poetic verses are proverbs. There are two images in this article. These are mullahs and masters. These verses were originally formed as separate proverbs. Each of them expresses a philosophical content that represents a common logical thought. In the article in the first verse, the teaching and learning of literacy in general in order to read and write is expressed in terms of the person who was educated in the madrasa, the mullah. He can also be described as "a master of his craft". In the second verse, "Masters run hand hoe" the idea is expressed that "no one can use an ax and a hand hoe like a master". The poetic formulation of these two proverbs stems, first, from the specificity of the epic to the lyro-epic genre. Second, "bringing together equal formal expressions, which mean that independent images have equal but 
independent functions, to achieve their ending with mutually synonymous words, that is, rhyming is the product of the wisdom and art of the people" [6, p. 11-12]. Fozil Yuldash oglu said that the Swallow's mother had to go to Kalmykia as soon as possible to show that the value of time and opportunity is very important in human life. Her mother was in a quarrel with Barchin, and if she didn't arrive on time, she might lose Barchin:

Don't bother yourself with harassment here,

\section{Go early; don't put off your work (A-76).}

In the vernacular, he has a number of options, such as "Do not put off today's work until tomorrow", "Time is precious, time will pass", "Your time is gone - your happiness is gone", "You won time - you won happiness" [7, p. 403407].

The proverb "A friend speaks bitterly, an enemy makes you laugh" or "A friend weeps, the enemy laughs" is widely used in our language. It is known that "a true friend only benefits, he does not miss evil, he does not harm. Even if he speaks harshly, he should not be upset. This is because he does so only to turn people away from the wrong path, out of resentment. He now writes, "An enemy treats you making you laugh, a friend treats you making you cry", "Be afraid of man who speaks laughing, and woman who speaks crying, "Stone thrown by friend does not harm you", There are many options, such as "Don't throw away the word of a friend, and or else you regret" [8, p. 98]. Fozil Yuldash oglu created a new model based on this proverb:

If it aims will get you known,
The friend makes you cry with the trust enemy laughs (A-21, 22, 73, 237, 243, 250, 318, 355) [9, pp. 13-16].

Our forefathers created many proverbs, emphasizing the need to strictly adhere to the etiquette of speech. In particular, in a series of proverbs such as "Yaxshi so'z bo'ldiradi, yomon so'z kuydiradi - A good word makes you get encouraged, a bad word burns", "suydirgan ham til, kuydirgan ham til - A tongue that dilute you and a tongue that burns tortures you" [10, pp. 87-79], "yaxshi so'z - ko'ngil podshosi - A good word is the king of the soul", "yaxshi so'z suyuntirar, yomon so'z kuyuntirar - A good word delights, a bad word burns" [11, pp. 457-458]. The difference between heaven and earth is revealed, the virtue of a good word touching a person, and the virtue of a bad word. The poet Fozil is based on the following proverbs:

The composers creatively reworked the proverb "Musicians play with the finger, a bad man burns with the language" (A-96), which resulted in its original appearance as an individual-author's speech.

The proverb “Qatorda noring bo'lsa, yoking yo'lda qolmaydi - If there is a reliable friend that your burden won't get left", is one of the most actively used common language units in our people. That is, there are a number of variants of this proverb, which are used in the context of "Nori bor, nori borning moli bor - Who has brave friend, he has good in hand", such as "Nor yo'lida yuk qolmas - Camel does not leave the good”, “Qush qanoti bilan uchadi, Quyrig'I bilan qo'nadi - The bird flies with its wings, It falls with its tail", (Annotated dictionary of Uzbek proverbs, 485), "Yuk og'irini nor ko'tarar, Dard og'rini er - The camel lifts the load, The burden of 
pain is borne by the man" (Uzbek folk proverbs, 222).

The general conclusion to be drawn from this is that relatives help and support a person in living and doing difficult things. The camel itself actually carries a heavy load. This complete idea was first applied in its own sense and then began to be applied in a figurative sense on the basis of metaphorical meaning. In the text of "Alpomish" this proverb came in several forms and served to figuratively express the camellike qualities of the braves:

Elda zo'raborim bordir, Qatordagi norim bordir; $(\mathrm{A}-56,68)$

I have violence in my nation,

There is a hero in the row;

Hakim degan mening mirzam bor edi, Qatorda gurkirab yurgan nor edi (A-214, 319)

I had a lord named Hakim,

There was a roaring light in the row.

Bu yurtda belgili bir qaysar edi,

Qatorinda chirqillagan nor edi. (A-359)

There was a certain stubbornness in this country,

There was a squeaking hero in the line.

At the same time, in the text of the epics, which is our source of study, the article "kishi yurti sira yurtlik qilmaydi - a man's country is not a country at all" (Uzbek folk proverbs, 14 ) reads “O'z yurtingning qadri o'zga yurtda bilinar - The value of your own country is known in another country", "Ayrilma o'sgan elingdan - Do not get betrayed from your nation"; the proverb
"A bird knows the language of a bird" (Parmeological dictionary of the Uzbek language, 275) is like "A woman knows the language of a woman"; "The adventurer finishes his work until the player thinks of the game" [12] (Parmeological dictionary of the Uzbek language, 257); or in the modern literary language, the proverb "Hut-yut - break or win" (Uzbek folk proverbs, 480), "Either live or died" (Parmeological dictionary of the Uzbek language, 90), formed on the basis of the seasons, representing happiness, luck, misfortune, occurs in the form "Either break or win":

Bir gap bilan bizlar bunda kelibmiz, Kun o'tkazmoq uchun tentib yuribmiz.

Kishi yurti sira yurtlik qilmaydi,

O'sgan el tinchligin ko'zlab turibmiz (yod., 21-b.);

In a word, we came here,

We wander to spend the day.

A man's country is not a country at all,

We seek peace in the land where we grew up

Erisin, tog'larning qori erisin,

Iloyim musofir yurti qurisin...(A-55);

Let the snow of the mountains melt, May my foreign land be built ...

Ket endi, qolma yo'lingdan,

Ayrilma o'sgan elingdan. (A-78);

Get out of the way now,

Separation from your grown land. 
Musofirman, hech ish kelmas qo'limdan,

Sen ayrilma o'ynab-o'sgan elingdan (A243);

I'm a stranger, I can't do anything,

You are separated from your grown-up land.

"Ayolning tilini ayol biladi - A woman knows a woman's language", said the old woman, as if to please Oyjamol. "I'm not going with you". We think, let us know our daughter's opinion too. We are an Aryan people. Our people are modest. When I ask you to come and see me, I say, "He has gone to seek a husband for his daughter” (Yod., P. 27); “Do not mumble just say". Tell the truth while you are spreading the word" (Yod., P. 67); When Yodgor heard this, he said, "This little boy has come to me; I see that the word is either break, or win, or used, or nothing is left. (Yod., 55-b).

The meaning of most of the above articles does not require explanation. However, the proverb "Yo hut, yo yut - Either break or win" from the language of Yodgor, who introduced himself as a "friend" in the epic and did not realize who the old man was, had a figurative meaning and served to express the fact that the hero can sometimes be forced to risk his life. In fact, hut is the Arabic name of the twelfth month of the solar year (February 22 - March 21). Hut went out and the porter came in. At the same time, that is, the end of winter, when the winter food supply was exhausted, the phrase "Hut-yut break-win" appeared in the speech to express the period when there was no grass for the animals on the ground [13. p. 566].

Over time, the text of epics has formed such aphorisms that some of them today are considered as a whole as proverbs, sayings, and wise sayings. In these cases, the meanings of advice often come to the fore.

For example, the use of

Xudo qozi, payg'ambarlar noyibi,

Urushda pand berar otning mayibi (A251, 318);

Judge of God, Viceroy of the Prophets,

The cripple of a horse that gives reason in war.

Qozining oldinda shabgir noyibi,

Yigitga pand berar otning mayibi (A312, 346)

In front of the judge is the deputy,

The crippled horse that gives the young man a reason.

in the text of "Alpomish" in the text of the work underwent some changes in connection with the poetic and stylistic requirements, which led to the emergence of variability, syntactic parallels. Apparently, the use of proverbs and their variants in different forms in the text of the work depends on the richness of the common language and the ability of the creator to use these language units, as well as individual approach.

3. Oral proverbs found only in the epic itself.

It is commendable that Fozil Yuldash oglu, a representative of the Kipchak dialect, used original proverbs in his epics, which are not found in the literary language. In particular, the transfer of state power to Ultontoz in the epic "Yodgor" and the news that Alpomish was taken prisoner in Kalmykia, like many, shocked his childhood friend, relative and comrade 
Shamirat and his relatives. The reason is that when two friends were young, they promised that if they had a child, they would be a boy, and if one of them was a boy and one was a girl, they would be a bride. Ay Barchin sends an old woman to Shamirot's door to fulfill Alpomish's promise, sweeps it, and announces that the promise has been fulfilled. But in such a situation Shamirot and his descendants decide to move from Boysun. So Barchin asks him to give her something valuable, indicating that her future cousin is Oyjamol cousin, otherwise she will ask her daughter to answer. Then, in the text of the epic, the proverb in Ay Barchin's speech served to express the reality clearly and concisely, to describe the processes connected with this situation: Hearing this word, Barchin said: - O God! As the saying goes, "Qo'noq ustiga cho'noq - A crowd over the settle" your words were amazing. Our panic is now pluralizing to ourselves (p. 10).

As it is known, a qo'noq is a guest invited to a wedding or parties. So, from the second part of the proverb, it is clear that the arrival of unexpected people in addition to the guest will hasten the owner of the wedding or event. There are times in life when, when a person is dying, exhausted, and distressed, another person comes and puts him in a worse situation, instead of comforting him, sympathizing with him, hurting his heart, insulting him, insulting him, upsetting him. . In this and similar cases, this proverb has the following meanings: "O'lganning ustiga tepgan

- Kicked on the dead", "o'lganning ustiga ko'mgan - Buried on the dead", "o'ldirganning ustiga - o'n tayoq - On the murderer - ten sticks", "dard ustiga chipqon - sick on pain" (Parmeological dictionary of the Uzbek language, 256).
There are also proverbs in Uzbek such as “Nodonni siylasang, chorig'i bilan to'rga chiqar If you respect a fool, you will be caught in the net with your shoes", "Borning yuzi yorug', yo'qning yuzi choriq - The face of the boar is light, the face of the boar is a shoe" formed by the lexeme of quarter. In fact, the shoe is a shoe made of hard raw leather, which is a picture mainly among the peoples of mountainous areas. It is based on the combination of dragging shoes - one means to live without two and without begging for anything [13, p. 510].

In the epic "Alpomish" the figurative compound formed by the lexeme of the foot is in the text of the work with a unique new interpretation by the poet Fozil: Hearing this word, Alpomish said: - Grandfather, you be me, I will be you, who is friend, who is enemy, own let me see with my own eyes that no one slips on someone's foot and dies" (A-333).

Or "Kulchali bola suymali bo'ladi - A child with a loaf of bread", "Soli suvga ketgan - Soli went for water", "So'ngi kelgan sangrov - who comes last is crazy", "oqsoqning oxiriga boq - Look at the end of the lame" can be included in the list of such proverbs: I am an old man among you. I'd like to go dry. There is a saying "Kulchali bola suymali bo'ladi - A child with a pudding will be a lover". Don't be as dry as I am, and don't put your hands on your noses. We don't need to go and see one. If it is convenient, we are going to be married (Yod., P. 25); Hearing this from Yodgor, his father asked, "What is this?" "So'ngi kelgan sangrov - who come last is crazy"; I don't understand "Speak, if you know", said to Barchin. Barchin then narrated the intention of Alpomish, that he had mistaken Shamirat's daughter, for what had happened (Yod., P. 36); The monument heard the word and said goodbye to old Chandana. 
He said to himself, "Look at the end of the lame". Whatever happened. Now, let me go to the foot of it and see what happened (Yod., P. 58); The wrestlers looked on. Jaynar is coming; "Soli suvga ketgan - Soli went for water" he said. The wrestlers said: "It seems that he is ashamed of himself in his speech (Yod., 74). The proverbs used to confirm this idea.

\section{CONCLUSION}

In general, the following general conclusions can be drawn from the observations:

a) Most of the articles in the text of the epics we have considered are used in literary language, as well as in most Uzbek folk dialects. In particular, "Sulton suyagini xorlamas - The sultan does not despise the friend", "ikki yorti bir butun- two halves a whole", "sichqonning ini ming tanga bo'lmoq - the mouse's nest is a thousand coins", "Do'stga zor aylama, dushmanlarga xor - Do not oppress a friend, despise enemies", "omonat - omonat qilmaysan xiyonat - deposit - betrayal you do not make a deposit", "esing borida etagingni yop take yourself into control while you are conscious", "sabr tegi sarig'oltin - patient it the key to the happiness" are among them.

b) The phenomenon of variability is also common in articles used in the text of epics. It has been observed from the analyzed articles that some of them have evolved from one another on the basis of various changes, have merged into one source, and have an image underlying them. They were told in Alpomish:

1. Mullalar o'qiydi zeru zabarni, ustalar chopadi tesha-tabarni - Mullahs recite duos; peasants dig the land Mullahs recite zeru zabar, Masters run tesha-tabar (A-83), variants such as "Mulla bilganin o'qir, bo'zchi bilganini to'qir - Mullah recites what he knows, weaver spins what he knows", "Mulla bo'lsang, takror qil, dehqon bo'lsang shudgor qil - If you are a mullah, repeat, if you are a farmer, cultivate", or swearing, "If it aims will get you known, The friend makes you cry with the trust enemy laughs" (A-21), "do'st achitib gapirar, dushman kuldirib - A friend speaks bitterly, an enemy makes you laugh, "do'st yig'latib gapirar, dushman kuldirib - An enemy treats you making you laugh, a friend treats you making you cry", It can be shown that it is formed on the basis of options such as "do'st yig'latar, dushman kuldirar - A friend weeps, the enemy laughs".

c) In the epics, especially in the text of "Alpomish" there are a number of proverbs or wise sayings of the proverb type, created due to the individual skill of Fozil Yuldash oglu, which served as one of the factors ensuring the individual innovation of the creator: "Sozandalar sozin chertar qo'l bilan, yomon odam kuydiradi til bilan - Musicians play with the finger, a bad man burns with the language" (A-96); "qasd aylasa bilmaganni bildirar, do'st yig'latib, dushmanini kuldirar - If it aims will get you known, the friend makes you cry with the trust enemy laughs" (A-21); Xo'ja kelsa chiqar murid naziri, xotin bo'Imasmikan erning vaziri - When the master comes, he is the minister of the murid, the minister of the husband, whether he is a wife or not?! (A-27).

This principle can also be applied to the articles in the text, if the language element involved in any text is based on the idea that it performs lexical-semantic, grammatical-stylistic functions. This is directly related to the proverbs found in the text of the epic "Alpomish" and "Yodgor". They, along with 
other linguistic-stylistic means, served to make the narrative of the epic figurative. But the peculiarity in the application of these proverbs is that they retained the main content, and in most cases were applied with some structural changes, and this happened in connection with the poetics of the epic. The creation of new proverbs and aphoristic sentences on the basis of existing models in our language should be understood as the result of Fozil Yuldash oglu's perfect knowledge of the vernacular and his poetic, epic narration skills;

d). In the text of the epics the following articles devoted to oral speech and dialectal forms "Qo'noq ustiga cho'noq - A crowd over the settle", "Kulchali bola suymali bo'ladi - A child with a loaf of bread", "Soli suvga ketgan Soli went for water", "So'ngi kelgan sangrov who comes last is crazy", "own let me see with my own eyes that no one slips on someone's foot and dies" were also observed. Some of them ("Soli suvga ketgan - Soli went for water", "So'ngi kelgan sangrov - who comes last is crazy") are not even reflected in the dictionary of modern proverbs. Hence, continuing such observations in the future and including them in existing dictionaries will also serve to increase the richness of our native language.

\section{REFERENCES}

1. Speech by the President of the Republic of Uzbekistan Shavkat Mirziyoyev at the opening ceremony of the International Festival of Bakhshi Art // "O'zbekiston ovozi” socio-political newspaper. №28-29. April 8, 2019.

2. Abdurahmonov X. (1971) Observations on the syntactic features of Uzbek folklore. Tashkent; Urinbaev B., Tursunov S. (2009) Lexico-phraseological features of the saga “Alpamysh". - Samarkand; Urinboev B.,
Bozorboev K. (1998) Interpretation of the phraseology of the epic "Alpomish". Samarkand; Toychiboev B. (2001) "Alpomish" and folk language. - Tashkent; Yuldashev Q. (2002)Interpretations of “Alpomish". - Tashkent. Xaliqov A. (2009) Lexical and semantic features of the language of the epic "Birth of Gorogly": Candidate of Philological Sciences. Dis. avtoref. - Tashkent. - p. 26.

3. Doniyorov X. (1979) Vocabulary of Kipchak dialects. - Tashkent. Doniyorov X., Abdusaidov A. (1987) Stylistic features of articles in the language of periodicals // Issues of Uzbek language stylistics and speech culture. A collection of scientific articles. - Samarkand. - pp. 10-17; Berdiyorov H., Rasulov R. (1984) Paremiological dictionary of the Uzbek language. - Tashkent; Hakimov M. (1965) About proverb terms // "Uzbek language and literature" magazine, -№ 2. - pp. 19-24 ; Mirzakarimova O. Linguistic features of some articles in "Devonu lugotit turk" // "Uzbek language and literature" magazine, 1980. -№3.- pp. . 31-35; Karimov S. Artistic style and means of expression of language. - Samarkand, 1994; Yuldashev B. (1993) Functional and methodological $f$ eatures of phraseological units in modern Uzbek literary language: Doctoral dissertation. avtoref. - Tashkent. - p. 49; Soatov B. (1992) Comments on the poetics of Uzbek folk proverbs // "Uzbek language and literature" magazine. -№5-6. - pp. 41-44; Usmonov N. (1992) Terms of education in folk proverbs // Journal "Uzbek language and literature”. -№1-2. - pp. 35-37; Jo'raeva B. (2002) Linguistic position and spiritual-methodical application of 
proverbs: Candidate of Philological Sciences. Dis. avtoref. - Samarkand. - p. 24.

4. Xaliqov A. (2009) Lexical and semantic features of the language of the epic "Birth of Gorogly": Candidate of Philological Sciences. Dis. avtoref. - Tashkent. - pp. 10-12.

5. Uzbek folk proverbs (Compilers: T.Mirzaev, A.Musakulov, B. Sarimsakov). Tashkent. Sharq. 2003. - p. 141.

6. Soatov B. (1992) Comments on the poetics of Uzbek folk proverbs // "Uzbek language and literature" magazine. -№5-6. - p. 42; Xaliqov A. (2009) Lexical and semantic features of the language of the epic "Birth of Gorogly": Candidate of Philological Sciences. Dis. avtoref. - Tashkent. - pp. 1112.

7. Uzbek folk proverbs (Compilers: T.Mirzaev, A.Musakulov, B. Sarimsakov). Tashkent: Sharq. 2003. - pp. 403-407.

8. Shomaqsudov Sh., Shorahmedov Sh. (1990) Wisdom. Annotated dictionary of Uzbek proverbs. - Tashkent. - p. 98.

9. Urinbaev B., Bozorboev K. (1999) Phraseologisms in the epic "Alpomish" // "Uzbek language and literature" magazine. № 4. - pp. 13-16.

10. Uzbek folk proverbs (Compilers: T. Mirzaev, A.Musakulov, B. Sarimsakov). Tashkent: Sharq. 2003, - pp. 78-89. The following places are given in the form of Uzbek folk proverbs - abbreviations Uzbek folk proverbs.

11. Shomaqsudov Sh., Shorahmedov Sh. (1990) Wisdom. Annotated dictionary of Uzbek proverbs. - Tashkent. - pp. 457-458. The following is an annotated dictionary of Uzbek proverbs - abbreviated Annotated dictionary of Uzbek proverbs.
12. Berdiyorov H., Rasulov R. (1984) Paremiological dictionary of the Uzbek language. - Tashkent. In the following places the paremiological dictionary of the Uzbek language is given in the form of the abbreviation Parmeological dictionary of the Uzbek language.

13. Annotated dictionary of the Uzbek language. Vol 5 - Tashkent. National Encyclopedia of Uzbekistan. - p. 566. 